\title{
Estimates of Genetic Components for Yield and Related Traits in Cocoyam
}

\author{
K. K. Paul ${ }^{*}$ and M. A. Bari \\ Institute of Biological Science, \\ Rajshahi University, Rajshahi-6205, Bangladesh. \\ "Corresponding author and Email: krshnnd@yahoo.com
}

Received: 26 April 2012

Accepted: 15 November 2012

\begin{abstract}
In the present investigation attempts were made to estimate genetic parameters for yield and its components in 315 genotypes of cocoyam collected from thirteen aroid growing districts. Plant height, petiole length, petiole breadth, leaf number, leaf length, leaf breadth, LAI, Inflorescence length, peduncle length, spathe length, spathe breadth, corm length, corm breadth, cormel number, cormel length, cormel breadth, corm weight, cormel weight, total fresh weight, total dry weight, yield per plant were taken in this study. Presence of significant differences together with wide ranges of variation indicates wide range of variability existed among the genotypes of cocoyam. Genotypic variances and coefficient of variation for most of the characters were remarkably higher than their corresponding environmental variances, which also indicate the existence of variation in genotypic level. Plant height, petiole length, leaf length, leaf breadth for cocoyam expressed high heritability with moderate to high genetic advance signalled heritable in nature. High heritability with high genetic advance in percentage of mean was also observed for plant height, petiole length, petiole breadth, leaf breadth, leaf number, LAI, corm length, corm weight, cormel weight in cocoyam.
\end{abstract}

\section{Key words: Accession, cocoyam, genetic variability, heritability, maulavikachu}

Cocoyam (Xanthosoma sagittifoium L. Schott) locally called maulavi kachu is important vegetable in Bangladesh and it contributes a considerable part of the total supply of bulky vegetables particularly when the vegetables are scarce in the market (Ahmed and Rashid, 1975). The edible species of cocoyam was originated in tropical America, but are now widely grown as a subsistence food crop in Asia, Africa and Polynesia. It is the most important export crop of all the root and tuber crops grown in Nicaragua (Bown, 2000). It can be compared favorably in nutritional value with other root crops such as cassava, yam and sweet potato (Plucknett et al., 1970). In Bangladesh very little research works on edible aroids have been done. Here it is absolutely an under utilized crop and not yet accepted as a general crop in the past to the farmers. Rapid population growth is demanding increased production and greater diversification of crops. Roots and tuber crops can play a major role in addressing this issue, which in many countries are treated just as a vegetable. Research on these crops rarely is high on the agenda of many countries. Germplasm characterization and evaluation address the existing genetic variability that acts as a supporting backbone for providing basic information towards improving the crop plant. Variation present in the genotypes is the basis of crop improvement. Any breeding program for improving the genetic pattern of crop plant 
depends upon the nature and magnitude of variability and the extent to which the desirable characters are heritable (Dudly and Moll, 1969). The genetic variability in a population along with heritability gives a reliable idea of the genetic advance to be ejected from selection for a given character (Burton, 1952; Johnson et al., 1955). Genetic variability is an essential prerequisite for crop improvement program for obtaining high yielding varieties. Tuber yield is a complex character and governed by the number of component characters. For rational approach towards the improvement of yield selection has to be made for the components of yield. Plucknett et al. (1970) have listed more than 300 cultivated varieties from pacific region; Hawaii alone accounts for more than 200 genotypes. Likewise a large number of genotypes are under cultivation in Fiji, New Zealand, Tahiti, Indonesia, Philippines, Tonga, Cook Islands, Malaysia, Samoa, Burma and India. Thus, the present investigations was designed for collection and evaluation of edible genotypes and estimate the genetic variability, heritability, genetic advance for identification of genotypes from local cocoyam germplasm.

Cocoyam genotypes (cormels/ plantlets/ suckers) were collected from different aroid growing pockets in the country, such as Arani, Godagari and Meherchandi of Rajshahi, Tala of Satkhira, Churamonkati and of chougacha of Jessore, Santhahar of Bogra, Panchbibi of Joypurhat, Munshiganj and Joydebpur of Dhaka, Madhupur of Mymensingh and sadar upozilla of Barisal in Bangladesh. Collected propagules were maintained at the experimental farm of the Institute of Biological Sciences, University of Rajshahi. The genotypes were grown in loamy soil in a single row of 4 meters length with inter row spacings of $45-100 \mathrm{~cm}$. The aroids were grown on set of rainy season of last week of March, 2006. Selected plantlets and plant parts (plantlets, corm and cormels) were used for propagating materials. Two healthy propagules were planted per hill during plantation and finally a single healthy plant was maintained.
This investigation was conducted at the experimental farm of the Institute of Biological Sciences research field at Rajshahi University, Rajshahi during the on set of rainy season 20052006. The land in which the experiment was carried out was medium high. The soil was part of Level Barind agroecological zone marked by sandy loam with $\mathrm{pH}$ 6.5. The rainfall distribution in rabi season was very low or scanty $(<40 \mathrm{~cm})$. So that at least 4 times flood irrigation were necessary. All recommended agricultural and intercultural practices were used in cocoyam production. The experiment was set up in a Randomized Complete Block Design (RCBD) with three replications. In each experimental plot plant propagules were planted with row to row spacing $0.70 \mathrm{~m} \mathrm{X} 0.70 \mathrm{~m}$ was maintained. When the vegetative growth is in climax then the agromorphological data were collected. When plant and vegetative growth was stunted, leaves become yellowish and dry then the quantitative parameters were observed and data were recorded following descriptors of Taro with necessary modifications (IPGRI, 1989). The morphological characters were recorded from randomly selected five plants from each genotypes between 170 - 190 days after planting, while yield and other characters were recorded at harvest. Leaf observations were made on three fully developed leaves per plant. Data were recorded from the plot of each replication in plant height, petiole length, Petiole breadth, Leaf, Leaf breadth, Leaf number, Leaf area Index, Corm length, Corm breadth, Cormel length, Cormel breadth, Cormel number, Cormel weight Corm weight, Total dry weight, Total fresh weight and Yield per plant.

The collected data were analyzed following the biometrical techniques of analysis developed by Mather (1949) based on mathematical model of Fisher et al. (1932) using the SPSS and excel software. Mean and Critical differences were worked out by the method of analysis of variance used for randomized block design. Data analysis was done separately for each character. Coefficient of variability at phenotypic, genotypic and environmental levels was 
computed following Johnson et al. (1955) and Burton and De Vane (1953). Variance analysis and genotypic variance $\left(\sigma_{\mathrm{g}}^{2}\right)$, phenotypic variance $\left(\sigma_{\mathrm{p}}^{2}\right)$, and environment variance $\left(\sigma_{\mathrm{e}}^{2}\right)$ were estimated following Singh and Chaudhary (1977). Broad sense heritability was estimated using the formula of Johnson et al. (1955), Hanson et al. (1956) and Warner (1952). The expected genetic advance for different characters under selection was estimated by the formula suggested by Allard (1960) and Lush (1949). Genetic advance in percentage of mean was calculated from the formula given by Comstock and Robinson (1952).

For better and perfect evaluation of Bangladeshi genotypes of cocoyam, the conventional tools in the field of biometry were used in the present investigation. In Bangladesh there are wide range of variations in aroids some are edible and some are very much wild as distinct by their acridity.

A total of 315 genotypes of cocoyam were collected from thirteen most edible aroids growing districts of Bangladesh (Table 1). All of the characters showed variation in their mean performances with respective to standard errors and critical differences (Table 2). The analysis of variance indicated significant difference among the genotypes for all characters studied except spathe breadth, sucker number, corm length, cormel number and total dry weight. The phenotypic, genotypic and error variances, the estimates of genotypic, phenotypic coefficient of variation, heritability in broad sense, genetic advance and genetic advance in percentage of mean were presented for all characters in Table 2. High range of variation was observed for all the studied characters, which pronounced the existence of wide scale variability. Phenotypic variances for all the characters were found higher than their corresponding genotypic and environmental variances as expected. But on close comparison between the magnitude of phenotypic and genotypic variances and coefficient of phenotypic variability, it was seen that the magnitude of phenotypic variances and coefficient of variability were much higher than their corresponding genotypic values in all the characters. Spathe breadth, corm length, cormel number, sucker number and yield per plant were influenced by environmental factors and rest of all the characters are governed by genetic factors. It indicates that though the variations for these characters are genotypic in nature but the major position of the phenotypic variances were contributed by the effect of interaction of genotypes and environment. Almost all characters exhibited higher phenotypic variances than their corresponding genotypic variances, but the differences between $\sigma_{\mathrm{p}}^{2}$ and $\sigma_{\mathrm{g}}^{2}$ were somewhat smaller or in considerable level. Higher $\sigma_{p}^{2}$ together with lower $\sigma_{e}^{2}$ than $\sigma_{g}^{2}$ for these characters suggested the existence of genetic variability, but the phenotypic variations were also moderately influenced by the environment as well as interaction of different levels. Excepting cormel number (36.14\%), total dry weight $(2.86 \%)$ and yield per plant $(23.45$ $\%)$ most of the characters exhibited high heritability. Highest to moderate genetic advances were found for plant height (135.26), petiole length (92.99), leaf length (71.91) and leaf breadth (54.03). Excepting corm length (8.56), cormel number (44.63), cormel breadth (32.38), total dry weight (0.54) and yield per plant (17.71), rest of the characters exhibited high genetic advance in $\%$ of mean. From the heritability analysis it was shown that the characters corm length, cormel number, total dry weight and yield per plant exhibited low heritability. Rest of all characters exhibited high broad sense heritability percentage which suggested lower environmental effects on these characters. High heritability coupled with moderate to high genetic advance was found for plant height, petiole length, leaf length, leaf breadth and cormel length. Presence of high heritability coupled with moderate to high genetic advance indicating prepondrance of additive gene action for these characters so that selection will be meaningful. Heritability with low genetic advance indicate the symptom of non additive gene action due to dominance and epistasis. Low heritability with low genetic advance expressed by corm length, cormel 
Table 1. List of cocoyam genotypes collected from different aroid growing districts in Bangladesh

\begin{tabular}{|c|c|c|c|c|c|c|c|c|c|}
\hline \multirow{2}{*}{ Accession no. } & \multirow{2}{*}{ Major groups } & \multirow{2}{*}{$\begin{array}{l}\text { No of } \\
\text { collections }\end{array}$} & \multicolumn{2}{|c|}{$\begin{array}{l}\% \text { of groups in } \\
\text { collection }\end{array}$} & \multirow{2}{*}{$\begin{array}{l}\text { Growing } \\
\text { conditions }\end{array}$} & \multirow{2}{*}{$\begin{array}{l}\text { Colour of } \\
\text { corm flesh }\end{array}$} & \multirow{2}{*}{$\begin{array}{l}\text { Palatibiliy } \\
\text { of cooked } \\
\text { starch }\end{array}$} & \multirow{2}{*}{$\begin{array}{l}\text { Plant } \\
\text { uses }\end{array}$} & \multirow{2}{*}{$\begin{array}{l}\text { Place of collection } \\
\text { /district }\end{array}$} \\
\hline & & & cultivated & wild & & & & & \\
\hline Dha-5.1-5.20 & Mau (cocoyam) & 20 & 19.04 & - & Upland & White & Poor & Food & Dhaka (Dha) \\
\hline Gaz-5.21-5.39 & Mau (cocoyam) & 19 & 13.97 & - & Upland & Brown & Poor & Food & Gazipur (Gaz) \\
\hline Mun-5.24-5.54 & Mau (cocoyam) & 15 & 16.48 & $\begin{array}{l}3.29 \\
\text { Med. }\end{array}$ & Upland & Brown & Poor & Food & Munshiganj (Mun) \\
\hline Tan-5.55-5.76 & Mau(cocoyam) & 22 & 21.56 & & Upland & White & Poor & Food & Tangail (Tan) \\
\hline Sat-5.77-5.106 & Mau (cocoyam) & 30 & 17.75 & $\begin{array}{l}3.55 \\
\text { wild }\end{array}$ & Upland & White & Poor & Food & Satkhira (Sat) \\
\hline Khu-5.107-5.132 & Mau (cocoyam) & 26 & 20.15 & & Upland & White & Poor & Food & Khulna (Khu) \\
\hline Jes-5.133-5.154 & Mau (cocoyam) & 22 & 12.02 & & Upland & White & Poor & Food & Jessore (Jes) \\
\hline Raj-5.155-5.190 & Mau (cocoyam) & 36 & 18.18 & $\begin{array}{l}3.03 \\
\text { wild }\end{array}$ & Upland & White & Acceptable & Food & Rajshahi (Raj) \\
\hline Joy-5.191-5.209 & Mau (cocoyam) & 19 & 12.50 & & Upland & Brown & Poor & Food & Joypurhat (Joy) \\
\hline Bog-5.210-5.224 & Mau (cocoyam) & 15 & & & Upland & Brown & poor & Food & Bogra (Bog) \\
\hline Nao-5.225-5.249 & Mau (cocoyam) & 25 & 17.85 & & Upland & White & Poor & Food & Naogaon (Nao) \\
\hline Kus-5.250-5.281 & Mau (cocoyam) & 32 & 19.04 & & Upland & Brown & acceptable & Food & Kustia (Kus) \\
\hline Bar-5.282-5.315 & Mau (cocoyam) & 34 & 18.99 & & Upland & White & Poor & Food & Barisal (Bar) \\
\hline Total $=$ & & 315 & & & & & & & \\
\hline
\end{tabular}


Table 2. Estimates of genetic parameters for yield and yield contributing characters in cocoyam

\begin{tabular}{|c|c|c|c|c|c|c|c|c|c|c|c|c|c|c|c|c|c|}
\hline $\begin{array}{l}\text { Genetic } \\
\text { paramet } \\
\text { ers }\end{array}$ & PLH & PEL & PEB & LEL & LEB & LEN & LAI & CRL & CRB & CRW & COW & $\mathrm{CON}$ & $\mathrm{COL}$ & $\mathrm{COB}$ & TFW & TDW & YPP \\
\hline Range & $\begin{array}{l}\text { 137.- } \\
213.0\end{array}$ & $\begin{array}{l}92.0- \\
160.0\end{array}$ & $\begin{array}{l}9.00- \\
15.33\end{array}$ & $\begin{array}{l}45.0- \\
94.50\end{array}$ & $\begin{array}{c}44.50- \\
78.0\end{array}$ & $\begin{array}{l}3.00- \\
8.00\end{array}$ & $\begin{array}{c}0 . .20- \\
0.63\end{array}$ & $\begin{array}{l}10.0- \\
35.00\end{array}$ & $\begin{array}{l}12.0- \\
44.00\end{array}$ & $\begin{array}{c}0.10- \\
2.10\end{array}$ & $\begin{array}{l}0.15- \\
0.70\end{array}$ & $\begin{array}{l}3.00- \\
43.00\end{array}$ & $\begin{array}{l}7.00- \\
39.00\end{array}$ & $\begin{array}{l}6.00- \\
14.00\end{array}$ & $\begin{array}{c}0.25- \\
0.89\end{array}$ & $\begin{array}{c}0.07- \\
0.75\end{array}$ & $\begin{array}{c}0.30- \\
2.50\end{array}$ \\
\hline$\partial_{p}^{2}$ & 4582 & 2326 & 26.06 & 1319.8 & 745.13 & 150.41 & 0.12 & 17.80 & 115.86 & 0.32 & 0.074 & 39.56 & 468.3 & 5.58 & 0.588 & .0077 & 0.162 \\
\hline$\partial^{2} g$ & 4444 & 2176 & 24.90 & 1268.1 & 716.43 & 149.95 & 0.11 & -3.70 & 93.96 & 0.21 & 0.063 & 14.36 & 447.1 & 3.29 & 0.581 & .0002 & 0.038 \\
\hline$\partial^{2}{ }_{e}$ & 138.00 & 150.00 & 1.16 & 51.70 & 28.7 & 0.457 & 0.0042 & 21.50 & 21.90 & 0.11 & 0.011 & 25.2 & 21.8 & 2.30 & 0.0076 & .0075 & 0.124 \\
\hline $\mathrm{CV}_{\mathrm{P}}$ & 38.34 & 37.98 & 44.86 & 48.05 & 46.79 & 214.52 & 97.43 & 19.90 & 37.66 & 73.02 & 79.34 & 59.73 & 125.38 & 28.63 & 137.66 & 92.34 & 36.55 \\
\hline $\mathrm{CV}_{\mathrm{g}}$ & 37.97 & 36.35 & 43.85 & 47.10 & 45.37 & 214.20 & 95.62 & 9.15 & 33.91 & 59.29 & 73.01 & 35.98 & 122.50 & 21.9 & 136.84 & 15.62 & 17.70 \\
\hline $\mathrm{CV}_{\mathrm{e}}$ & 6.65 & 9.54 & 9.47 & 9.51 & 9.18 & 11.82 & 18.83 & 22.06 & 16.37 & 42.62 & 31.04 & 47.67 & 27.05 & 18.38 & 15.58 & 91025 & 31.90 \\
\hline $\begin{array}{l}\mathrm{h}^{2} \\
\text { (bs) }\end{array}$ & 96.98 & 93.95 & 95.54 & 96.08 & 96.14 & 99.63 & 91.66 & 20.78 & 81.04 & 65.93 & 85.13 & 36.14 & 95.47 & 58.96 & 98.80 & 2.86 & 23.45 \\
\hline GA & 135.26 & 92.99 & 10.04 & 71.91 & 54.03 & 25.18 & 0.672 & 1.80 & 17.98 & 0.76 & 4.74 & 4.70 & 42.57 & 2.87 & 1.56 & 0.0516 & 0.20 \\
\hline $\begin{array}{l}\text { GA } \\
\%\end{array}$ & 76.61 & 72.46 & 88.23 & 95.11 & 91.59 & 440.67 & 193.49 & 8.56 & 62.25 & 86.62 & 1378 & 44.63 & 246.6 & 32.38 & 280 & 0.54 & 17.71 \\
\hline
\end{tabular}

PLH= Plant Height, PEL = Petiole Length, PEB = Petiole Breadth, LEL = Leaf Length, LEB $=$ Leaf Breadth, LEN $=$ Leaf Number, LAI $=$ Leaf Area Index, CRL $=$ Corm Length, $\mathrm{CRB}=$ Corm Breadth, $\mathrm{COL}=$ Cormel Length, $\mathrm{COB}=$ Cormel Breadth, CON = Cormel Number, COW = Cormel Weight, CRW $=$ Corm Weight, TDW $=$ Total Dry weight, $\mathrm{TFW}=$ Total Fresh Weight, YPP = Yield Per Plant. 
number, cormel breadth, and yield per plant suggested the role of non additive gene action for the control of these characters. High heritability along with high genetic advance is more reliable than heritability alone in predicting the results of selection (Johnson et al., 1955). Reys Castro et al. (2005) worked on three cocoyam genotypes for phenotypic character evaluation on plant height, leaf number, number of secondary shoots, pseudostem diameter and leaf area of the penultimate leaf, number of cormels, mean cormel weight maximum diameter of the cormel, length of the cormels and yield per plant. They found that cormel weight was the only trait that differed significantly between the genotypes, while number of leaves, number of cormels and yield per plant differed between the two genotypes.

Plant height, petiole length, leaf length, leaf breadth expressed high heritability with moderate to high genetic advance proved to be heritable in nature. High heritability with high genetic advance in percentage of mean was also observed for plant height, petiole length, petiole breadth, leaf breadth, leaf number, LA, corm length, corm weight, cormel weight for cocoyam.

\section{References}

Ahmed, G. and Rashid M. M. 1975. A comparative study of the gross morphological characters and the yield potentialities of the major types of edible aroids of Bangladesh. Bangladesh Horticultutre, 3(1): 15 - 21.

Allard, R. W. 1960. Principles of Plant Breeding. John Wlley and Sons. Inc. N.Y. International Edition: 103 - 107.

Bown, D. 2000. Aroids. Plants of the aurum family, $2^{\text {nd }}$ education. Portland, Oregon: Timber Press, USA. 392 p.

Burton G. W. 1952. Quantitative inheritance in Grasses. Proc. $6^{\text {th }}$ Int. Grassland Cong., I: $277-283$.

Burton, G. W. and De Vane E. W. 1953. Estimating heritability in tall fescue (Festuea arundinaceae) from replicated clonal material. Agronomy Journal, 45: $478-481$.

Comstock, R. E and Robinson H. F. 1952. Genetic parameters their estimation and significance. Proc. $6^{\text {th }}$ Int. Grassland Cong., 1: 284 - 291.

Dudley, J. W and Moll R. H. 1969. Introduction and uses of estimates of heritability in Soyabean. Agronomy Journal, 47: 314 318.

Fisher, R. A., Immer R. R. and Tedin O. 1932. The genetic interpretation of statistics on the third degree in the inheritance of quantitative inheritance. Genetics, 17: 107 - 124.

Hanson, C. H, Robinson, H. F and Comstock R. E.1956. Biometric studies of yield in segregating populations of Korean Lespedeza. Agronomy Journal, 48:268-72.

IPGRI, 1989. Descriptors for cocoyam (Xanthosoma spp.). IPGRI, Rome, Italy.

Johnson, H., Robinson, H. F and Comstock R E. 1955. Estimates of genetic and environmental viability in soyabean. Agronomy Journal, 47: 314 - 318.

Lush, J. L. 1949. Animal breeding plans. Iowa State Univ. Press. Ames.

Mather, K. 1949. Biometrical genetics, Dover Publication. Inc. New York.

Plucknett, D. L., Pena, R. S. and Obrero R. T. 1970. Taro (Colocasia esculenta). Field Crops Abstracts, 23: $413-426$.

Reys Castro G., Nyman, M. N. and Ronnberg Wastljung A. C. 2005. Agromic performances of three cocoyams (Xanthosoma violaceum Schott) genotypes grown in Nicaragua. Euphytica, 142: 265 272.

Singh R. K. and Chaudhary, B. D. 1977. Biometrical methods in quantitative genetic analysis. Kalnani Publishers, New Delhi, India. 49 - 100.

Warner J. N. 1952. A method of estimating heritability. Agronomy Journal. 44: 427 430. 